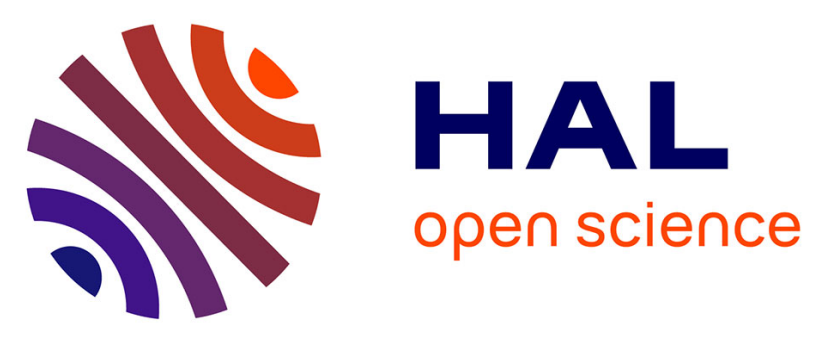

\title{
Culturally equipped for socio-scientific issues? A comparative study on how teachers and students in mono- and multiethnic schools handle work with complex issues.
}

\author{
Claes Malmberg, Malin Ideland, Mikael Winberg
}

\section{To cite this version:}

Claes Malmberg, Malin Ideland, Mikael Winberg. Culturally equipped for socio-scientific issues? A comparative study on how teachers and students in mono- and multiethnic schools handle work with complex issues.. International Journal of Science Education, 2010, pp.1. 10.1080/09500693.2010.519803 . hal-00639389

\section{HAL Id: hal-00639389 \\ https://hal.science/hal-00639389}

Submitted on 9 Nov 2011

HAL is a multi-disciplinary open access archive for the deposit and dissemination of scientific research documents, whether they are published or not. The documents may come from teaching and research institutions in France or abroad, or from public or private research centers.
L'archive ouverte pluridisciplinaire HAL, est destinée au dépôt et à la diffusion de documents scientifiques de niveau recherche, publiés ou non, émanant des établissements d'enseignement et de recherche français ou étrangers, des laboratoires publics ou privés. 


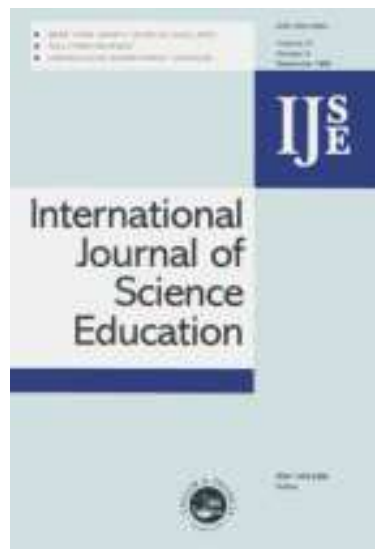

Culturally equipped for socio-scientific issues? A comparative study on how teachers and students in monoand multiethnic schools handle work with complex issues.

\begin{tabular}{|r|l|}
\hline Journal: & International Journal of Science Education \\
\hline Manuscript ID: & TSED-2010-0115.R3 \\
\hline Manuscript Type: & Research Paper \\
\hline Keywords: & discourse, multicultural, science education \\
\hline Keywords (user): & \\
\hline
\end{tabular}

SCHOLARONE ${ }^{\text {m }}$

Manuscripts

URL: http://mc.manuscriptcentral.com/tsed Email: editor_ijse@hotmail.co.uk 


\section{Introduction}

Earlier studies (Skolverket, 2007; Lee \& Luykx, 2007; Parszyk, 1999) indicate that the odds of immigrant students of succeeding in work with socio-scientific issues (SSI) are bad. They often have lower grades in science subjects, authentic media texts may constrict bilingual students and indications are also that students from families with low socio-economic status (SES) are advantaged by strict framing, which is less pronounced in SSI. The objective of this paper is to discuss how well-equipped students in multiethnic and monoethnic schools are for work with SSI and how SSI-education can become more successful. With this in mind, we would like to compare two student groups in Swedish lower secondary schools, since earlier research indicates a difference in their attitudes towards and abilities to work with SSI - that students from a 'Swedish' middle class background have better chances of working successfully with SSI than students from homes with foreign backgrounds and low socioeconomic status. Without talking about one or another group as the norm, we would like to analyse how these stated differences are manifested in answers from a questionnaire, and in activities in classrooms. Through a quantitative study we intend to analyse how students express their own notions about themselves as students in the science classroom, and how equipped they are for work SSI as content and method. With the help of a qualitative observation-study in two school classes, we intend to problematize the picture through analyzing their activities, and discuss why students might succeed or fail to succeed in working with SSI.

\section{SSI characteristics}

SSI are characterized as complex tasks, departing from a topical media-reported issue. They have a basis in science, but at the same time are lacking right answers. The work involves the forming of opinion through ethical evaluations, risk assessments and cost-benefit analysis. 
The texts that are used are authentic - not produced for the school context (Ratcliffe \& Grace, 2003; Ekborg, Ideland \& Malmberg, 2009). Work with SSI is often said to engage students in developing scientific knowledge as well as their interest in society (Ratcliffe \& Grace, 2003). Working with SSI is talked about as making school science important and usable outside the classroom, and outside the scientific discourse (Aikenhead, 2006). These are fine words, and seem to be extremely relevant today since science is no longer is an area exclusively for experts (Nowotny, Scott \& Gibbons, 2002). Science and society are interdependently-related in a complex way, and school science has a responsibility when it comes to development of students' scientific citizenship; that is, to understand, criticize and take part in public debate, make decisions and act in a responsible way (Elam \& Bertilsson, 2003). A growing awareness of the impact of science on society and the social, moral and ethical dimensions of science calls for a science education aiming at scientific literacy (Gray \& Bryce, 2006), in a 'rethinked way', as Roth and Lee (2004) discuss. They express the need for working with science as one tool among others in the handling of everyday life. An education which deals with socio-scientific issues is said to help students to develop competencies as 'informed decision-making' argumentation and discussion which are valuable tools when they need to make choices and take standpoints in everyday life.

Besides increasing the sense of usefulness of school science (its utility value), the cooperative work form, the high degree of intellectual autonomy, and the challenge that is assumed to be associated with the process of 'solving' SSI are factors that have been shown to stimulate intrinsic motivation by eliciting positive feelings of competence and relatedness (Ryan \& Deci, 2000). Thus, working with SSI might not only make students feel that science could be of value for them outside the school, but also that it is enjoyable per se - strengthening the students' self-efficacy and allowing for interaction with others and the pursuit of issues that 
are of personal interest. Positive evaluation of the SSI work (for example, its high utility and incentive value), together with a strengthened sense of competence, would not only lead to motivated behavior during the activity (Wigfield \& Eccles, 2000), but also affect future attitudes to this type of activities in a positive way (Ajzen, 2001; Eagly \& Chaiken, 1993). Similarly, from an extensive review of the literature on how to increase students' interest for science, mathematics and technology, Tytler, Osborne, Williams, Tytler \& Cripps Clarke (2008) concluded that involvement of students in the construction of knowledge, less focus on single correct solution pathways, and an increased intellectual challenge during learning would be highly beneficial for students' future engagement with these subjects.

\section{Media literacy and critical thinking}

Along with development of scientific knowledge, SSI is also said to build up students' abilities in for example ethical evaluations, media literacy and argumentation (Ratcliffe \& Grace 2003). But - and this is important according to our study- at the same time, these competences are prerequisites to a successful work with SSI. Without ability for critical thinking, argumentation and ethical evaluation, the SSI work easily falls flat. Research has however pointed out the importance of working with mass media in the science classroom in a conscious way (e.g. Norris \& Phillips, 2003; Gray \& Bryce 2006). Jarman \& McClune have in several research reports $(2002,2003,2007,2009)$ discussed how media literacy can be implemented in science education.

The approach of 'Ordinary teachers' to news media can, according to McClune and Jarman (2009), best be characterized as casual and unsystematic. The SSI-approach with goals to teach the students to criticize media texts and understand them as constructed news (Jarman \& McClune, 2007; Ideland, 2002) is not to be found in research on teachers' use of media in the science classroom (see also Phillips \& Norris, 1999; Millar \& Osborne, 1998; Levinson \& 
Turner, 2001; Elliot, 2006). Jarman \& McClune (2002, 2009) and Elliot (2006) point out teachers' lack of knowledge in media literacy as one reason for the unconscious use of media in science classroom. Halkia and Mantzouridis (2005) show that teachers consider press science articles as reliable source of scientific information.

Besides the lack of media literacy, Gray and Bryce (2006) show that teachers have difficulties in working with a humanistic perspective as well as with argumentation - and they often have difficulties in teaching how to develop these skills (Ekborg, Nyström \& Ottander, forthcoming). Levinson, Koulouris and Turner (2000) report that science teachers in England and Wales feel unable to discuss ethical issues with pupils in the classroom. Levinson and Turner (2001) claim that the majority of science teachers consider that their role is to present the "facts" of their subject and not to deal with associated social or ethical issues. The role of the science teacher is a 'dispenser of knowledge' (Ratcliffe et al 2005) rather than a rolemodel for learning and problem-solving. A consequence of this is the students' roles as receivers of facts from well-informed transmitters and as reproducers of previously-known knowledge rather than as learners and problem-solvers (Claxton 2008).

\section{Becoming a successful student in the science classroom}

Sadler (2009) presents situated learning as a theoretical framework for how to conceptualize work with socio-scientific issues. He points out the importance of studying learning in a socio-cultural context, in a specific community of practice in which students can develop and employ different discourses. Sadler's approach is relevant for our study, and the situated learning framework could have been used for understanding different students' possibilities and chances to succeed in work with SSI. However, to analyse students' and teachers' understanding of SSI as a work form, we are going to use another, but related, theoretical 
framework in which discourse is understood in a Foucauldian way, e.g. discourse as structuring the way we perceive and talk about the world (Foucault, 1981). Fairclough (1995) has pointed out the importance of understanding texts (in a wider perspective, also including activities) in relations to a) discursive practices and b) socio-cultural practices. In our case this leads to that we will analyse how students are trying to become successful in the science classroom in relation to a) school (and school science) as a culture with specific norms and values and b) norms and values in society regarding e.g. science, students from different backgrounds and the point of school.

School science classes can be understood to be structured both by a scientific discourse and a more general school discourse - in which the main aim for the students seems to be academic success rather than becoming a competent learner (Claxton, 2008). To become a successful student in this hegemonic school discourse, one needs to know the 'hidden curricula' - that is, learn to follow rules, talk only when allowed, always have the work under control, accept doing things one doesn't like and think that to help fellow students is to cheat (Broady, 1979).

In addition to the general school discourse, the science classroom is structured by a scientific discourse. Several researchers point out the importance of being included in this scientific discourse to understand school science (Lee 2003, Aikenhead 2006). Nyström (2007) writes that students with a non-Swedish background often are unable to identify themselves with a scientific discourse, which becomes yet another excluding mechanism. Sadler (2009) has however shown how SSI can be a way to shift focus, from a scientific community of practice to a more general one. Through SSI, it can become possible to include more students in a known context, compared to more 'traditional' science education. Other kinds of identities become, according to Sadler, promoted inside the science classroom. 
Inclusion in a field is not only about knowledge and language: normative power, social prestige and institutionalized privileges are also important (Lee \& Luykx 2007, Snively \& Corsiglia 2001). Banks (2008) points out the cultural difference paradigm as important in analysing immigrant students' failures in school science. Banks looks for the reasons for failures in the exclusion from the school science discourse from this perspective. Parszyk (1999) also shows how the Swedish school on a more general level is organised to suit students from the middle class, and that students from families with low social economic status and a different cultural background feel discriminated, feel that that they attend ' $a$ school for others' (which should be compared with the rhetorical and political goal 'a school for all').

Bernstein (1975) differentiates two orders in the school culture - an instrumental one and one expressive one - as an analytical tool to understand students' success or failure, taking school culture and family background into account. The instrumental order consists of those activities and procedures involved in the acquisition of specific facts, skills and understandings. The expressive order consists of those activities and procedures involved in the transmission of values and norms. Depending on for example academic experience and social class, students' families can support and understand either the instrumental order or the expressive order to different extents.

Classroom work with SSI is often carried out in a quite autonomous way, where the teacher preferably has a guiding role rather than being a deliverer of facts. SSI-work is also about dealing with questions without right answers, using texts not written for school purposes. Our question is about in what ways this work form suits different student groups. Earlier research 
has pointed out that students from families with low SES are advantaged by strict framing (Bernstein 2003). Lee (2003) points out difficulties working with inquiry-based learning in science class where many of the students have immigrant backgrounds. She argues for a teacher-explicit to student-exploratory continuum with explicit instructional scaffolding. She means that the challenge to succeed with this work form is more complex for students coming from cultures 'that do not encourage them to engage in inquiry practices of asking questions, designing and implementing investigations and finding answers on their own' (Lee, 2003 p 466).

Lee (2003) also stresses problems with students having an authoritative view of knowledge when conducting inquiry-based work. She writes that cultural norms may make the students see teachers and adults as authoritative sources of knowledge. The source of the knowledge seems more important than the evidence in the judgment of its credibility. According to Lundström (2009), however, this is not a problem restricted to immigrant students. He shows how students in upper secondary school science classes evaluate evidence based on authority rather than on scientific facts or knowledge-construction.

\section{Aim and methods}

Aim

The aim of the study is to analyse what happens when SSI as a work form is implemented in science classrooms with students from different backgrounds concerning socio-economic status and ethnicity. How do different student groups handle the use of authentic mass media? How do they cope with a - for them - new way of structuring the science teaching from SSI's objectives? In our analysis we consider the science classroom and its inhabitants (students and teachers) as a culture, with shared traditions, spoken and unspoken norms and values. 
We analyse how students' experiences of the work form and their strategies in the classroom can be understood from a) the degree of ethnic diversity; b) discourses on how school science is supposed to be, according to a school culture. We are also interested in studying how teachers structure the SSI work from discourses on what suits different students when it comes to use of authentic media sources and degree of student autonomy.

The article will now continue with an outline of the method, followed by empirical result sections. The result section starts with data from a quantitative study, which shall be viewed as a background to an ethnographic study on work with SSI. In this ethnographic study we are trying to understand and problemize the results from the quantitative study. Finally, we discuss our data with the help of the theoretical framework outlined above.

\section{Methods}

This paper is a result of the research project 'Science In a Societal Context' (SISC) ${ }^{1}$. The project has been conducted in three steps. In step 1, six SSI tasks were constructed. The tasks focused on issues regarding health, climate change, eye laser treatment, cochlea implants and risks with mobile phones. In step 2, these tasks were distributed to and carried out by 70 secondary school classes (1488 students in school year 6-9) in different parts of Sweden. The teachers got some instructions about how to introduce each case to the students, the minimum time required (5 hours) and the further requirement that the students must discuss the task in small groups on at least one occasion. The teachers had support from a teachers' guide - ideas about questions to ask and resources to use. The guide also included worksheets for the

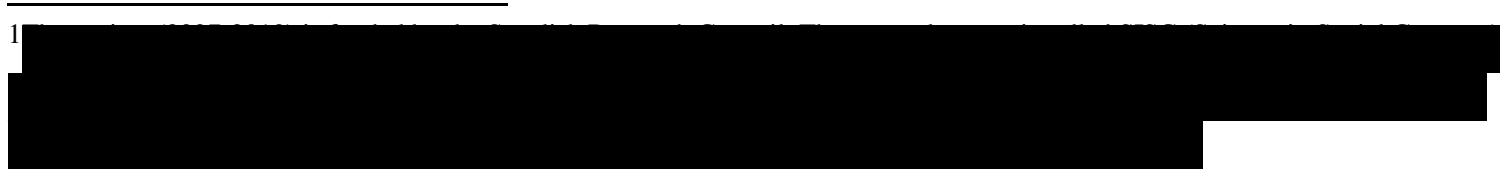


students together with more detailed background information on the issues and goals for each case for the teacher. But - important for the outcome we report in this article - we did not suggest detailed teaching sequences or work forms. Instead, the teachers were asked to work with the cases in a way they found appropriate in their regular work. In this step the students answered questionnaires before and after the SSI work (see below). Also the teachers answered a questionnaire after the work, and seven of them were interviewed.

In step 3 six new classes worked with three different SSI tasks. The same questionnaires were used and the teachers interviewed. We were also conducting an ethnographic fieldwork. This is described in more detailed below. The data in this article consists of results from both the quantitative and the qualitative study, and we are introducing the methods one by one, starting with the quantitative. The reason for combining two, quite disparate methodologies is that we will discuss how different patterns appear depending on the method, and how these can be understood from a cultural perspective.

\section{Quantitative method}

In step 2, the students answered one questionnaire before and one after the work.The questionnaire distributed prior to the SSI work aimed at measuring students' beliefs and attitudes towards learning science, attitudes towards the role of science in society, their selfefficacy when it comes to studying science, and what work forms they were accustomed to in science class After the SSI work, we distributed a questionnaire examining conditions under which the SSI work was performed, the students' affective experiences of the work, their behavior (effort and concentration), and perceived learning outcomes. In this article we are interested in analyzing differences (and similarities) between mono- and multiethnic student groups. As to put things into perspective, we also wanted to compare the influence of the 
degree of multi ethnicity on outcomes of the SSI work with the influence of other, more personal, variables, (e.g., attitude toward school science) and the SSI working conditions. The measure used to estimate the degree of 'multi-ethnicity' is the percentage of the students entitled to mother tongue tuition. Students' answers on the questionnaire items were subjected to Partial Least Squares analysis (PLS), a regression extension of principal component analysis (PCA), to explain the proportion of students entitled to mother-tongue tuition in each specific school. Since the percentage of students entitled to mother-tongue tuition was calculated on a school level, the averages, rather than individual student responses to the questionnaire items, in each school were used in the analysis. As a measure of the degree of the relative strength of the link between the students' responses to the questionnaires and the degree of multiethnicity, 'Variable Importance for Projection' values (VIP) were calculated for each questionnaire item. This procedure is basically a way to summarize the loadings of an individual item on the components in the PLS model, weighted by the amount of variation in the multiethnicity that is explained by each component. The number of components to retain in the PLS models was decided using the cross validation procedure described by Eastment and Krzanowski (1982), i.e., each component must add a significant amount of predictive ability to the model. Standard procedures were applied to assess the quality of models $^{2}$

For the sake of brevity, unless these tests indicated problems, $\mathrm{R}^{2}$ and $\mathrm{Q}^{2}$ values are the only quality indices reported below. While the $\mathrm{R}^{2}$ informs us about the proportion of the total variation in the variables that is described by the model components, $\mathrm{Q}^{2}$ is pertinent to the

\footnotetext{
${ }^{2}$ Residuals were checked for normality, Hotellings were calculated (displayed as an elipse in the loading plots) to assess any undue leverage from observations with extreme positions in the direction of the components.Moderate outliers were detected by measuring the DmodX (i.e., the distance between observations and the model hyperplane in the multivariate variable space). Model validity was tested by response permutation procedures, i.e., the predictor variables were kept intact while responses (in this case, the degree of multiculturality) were permutated 20 times. After each permutation, a new model was calculated and compared to the original PLS model with respect to its descriptive and predictive ability.
} 
proportion of variation in the dependent variable that can be predicted by the model. The statistical package used for multivariate analysis was SIMCA P 11+ (Umetrics, 2004).

\section{Qualitative method}

In step 3, six classes were working with three different SSI tasks. The qualitative data in this specific article however comes from two classes from different schools. In the first school, which we call Multi-ethnic school, all the students have a non-Swedish ethnic background, and the school is situated in an urban area with high ethnic diversity, low SES and low educational level. In the other school, here called Monoethnic school, all the students have a Swedish ethnic background and the school is situated in a village with low ethnic diversity, high SES and high educational level. In a Swedish context, a multiethnic school is an expression of segregation inside cities. Multiethnicity is - both on a discursive and a concrete level - connected to low economic status and also cultural status. The schools are often situated in high-rise development areas with low standard of living. The inhabitants in these segregated areas are often refugees from countries outside Europe, e.g. Afghanistan and Iraq but also from former Yugoslavia. This ethnic mixture also characterizes the studied multiethnic school. The income is low and the parents might have education from their home countries, but have difficulties to use it in Sweden. And, which is important, the public opinion of these areas and schools is that they are culturally and economically deprived (Lorentz, 2009; Ristilammi, 1994; Sandström, 2004). We are fully aware of that by using the concepts (and even names) multiethnic and monoethnic school, we are reproducing the discourse that the different schools are contradictory to each other, we are contributing to the "Us" and "Them" dichotomy. However, since this public - and also in some cases scientific discourse is so strong; we are interested in investigating how this notion of dichotomy is expressed by students and teachers. We do not believe that differences can be explained due 
to ethnicity, but that discourses on ethnicity and socio-cultural status influence how teachers and students act in the classroom. In other words, the consequence of this perspective is that we are not interested in analysing how different ethnic student groups, e.g. "Arabs" or "Swedes", are acting in the work with SSI, but how classroom cultures are constituted by (and constantly constituting) discourses on how "immigrant students" and "Swedish students" are favoured by different work forms and norms.

The qualitative data used here consisted of classroom observations, 12 lessons, six from each school. Each observation lasted for about one hour and each time at least two observers were present, taking field notes and recording group discussions. A semi-structured observation protocol was used, which pointed out the direction for the observation into trying to understand what makes SSI as a work form successful (or not) with regard to students' interest and learning in school science.

An ethnographic approach was used for observations of how teachers and students handled the work with socio-scientific issues. Ethnography can be described as a family of methods which are used to analyse everyday practices as cultural (or discursive) practices ( $\mathrm{O}^{\prime}$ Reilly, 2005). In other words, we are trying to capture what is happening in the classroom (and why) - not just evaluate from a structured observation protocol. Willis and Trondman (2000) stress the "understanding and representations of "experience", as central in ethnography (p 6). We consider the classrooms as cultures, with shared traditions, norms and values, in which discourses are constantly produced and reproduced. The studied classrooms are in other words unique, but at the same time arenas where more general discourses are expressed. This means that deep knowledge from the specific case might be useful to understand another, but similar, context. To quote Cronbach (1975): “When we give proper weight to local conditions, any 
generalization is a working hypothesis, not a conclusion" (p 125). It is not possible to generalize the qualitative (or quantitative) results, but the experiences gained in this study might help researchers to pose new relevant questions in similar projects. Our intention is to show how orders of different discourses influence the students' and teachers' work with SSI. The analysis of the qualitative data for this article has taken its starting point in the outcome of the quantitative data concerning differences between multi- and monoethnic student groups - since these themes seem to be important to the success of working with SSI. In other words, we have analysed how media use, school culture and view on knowledge seem to influence the SSI-work. These are the factors that stand out in the quantitative study (see below).

Characteristic for ethnography is to present the results through 'thick descriptions', through 'writing culture' (Clifford \& Marcus, 1986) and revealing discursive patterns. Typical for ethnographic writing is the intention to understand cultural norms and values through details. Willis \& Trondman (2000) write about the possibility of constructing 'Ah ha-effects' for readers through ethnographical writing; 'Ah ha-effects' that reveal hidden discourses, agendas and values through descriptions close to- in this case - the teachers and students themselves.

\section{Ethical considerations}

The schools and the individuals have been given false names for anonymity. In the qualitative study parents and students have given written consent. In school B, some students were left out of the observation study, since they did not consent to be a part of the research project. However they took part in the teaching activities. 


\section{Results}

In this empirical section, we will start by investigating what differences and similarities between the two groups of students (monoethnic and multiethnic) emerge in a quantitative study. The next step is to explore how these emerging aspects can be understood from a cultural perspective, and to discuss how the results relate to each other. Do people do what they say that they do, or more exactly, do people's responses in questionnaires correspond with their actions in the classrooms when it comes to their SSI experiences?

\section{Quantitative study}

To put things into perspective, this section starts with the results of a hierarchical PLS analysis, were the influence of the degree of multiethnicity on the perceived learning outcomes and students motivated behaviour during SSI work is compared with the influence of the SSI work forms, the students' attitudes toward science, epistemological beliefs ,attitudes towards learning, and self-efficacy beliefs. To facilitate interpretation, individual questionnaire items were distributed on different PCA "base models", according to their theoretical belonging. To ascertain that the base models were good representatives of the respective constructs, they were analysed for dimensionality (i.e., how items loaded on the components that emerged) and their ability to describe the variation in the students' responses to the items. For the sake of brevity, and since this procedure has been thoroughly described elsewhere (Winberg \& Lindahl, 2008), data on these analyses are not reported here. Students' scores on the components that emerged in these base models, instead of students' responses to the original items, were used as variables in a PLS top model (figure 1), aiming to explain the relationships between the outcomes and the different constructs (e.g., students attitudes towards science). Thus, since each of the components express a linear combination of several original questionnaire items, we have reduced the number of variables from 134 to 12. 


\section{The relative influence of multiethnicity on outcomes of SSI work}

Figure 1 shows the result of the PLS analysis of the relationships between students scores on the components in the different base-models and the outcomes. For example, the variable named "(1) SSI work forms" represents students scores on the first principal component in the base-model that was used to describe the variation in work forms during SSI work, while "(2) SSI work forms" represent students scores on the second component in the same base-model. These two base-model components are orthogonal to each other and thus describe two different aspects of the SSI work forms. The meanings of the components in the different base-models have been described elsewhere (Winberg \& Lindahl, 2008). Since, the purpose is to show the relative influence of the degree of multiethnicity on outcomes, we have chosen not to elaborate further on the other constructs in the PLS top model in this paper.

For those not acquainted with PCA and PLS, a brief description on how to interpret loading plots (e.g., figures 1 and 2 below) might be in place. Items located close to each other in the loading plot are positively correlated and (possibly) convey similar information. The further out from the origin of the plot an item is located (i.e., the higher loading it has, relative to the other items), the more important it is in the model. In PLS, a dependent variable located far out from the origin and in the same direction as the independent variable means that it is important for explaining variation in the dependent variable. In figure 1, the dependent variables "affective outcome" and "cognitive outcome" loads on both component one and two, meaning that both components are useful for explaining variation in them. Due to its high loadings on both component one and two, the independent variable "(1) SSI work forms" can be considered the most important variable for predicting affective and cognitive outcomes. Thus, from figure 1 , it can be concluded that the degree of multiethnicity cannot explain outcomes of the SSI work (i.e., positive affect, high effort and concentration, and perceived learning outcomes), as well as the work forms during SSI work, students' beliefs 
and attitudes about learning, and the students' self-efficacy in the school science context. To further clarify the relative importance of the different constructs for the explanatory ability of the PLS model, VIP ${ }^{3}$ values for the different constructs were calculated (table 1).

\section{Figure 1 Insert here.}

It should be mentioned that in this analysis, to increase reliability, the individual students' responses to the questionnaire items, (rather than school averages) and the schools' degree of multiethnicity, were used to explain outcomes. The resulting two-component model used $38 \%$ of the variation in the students' responses to questionnaire items, and the multiethnicity variable to predict $41 \%$ of the variation in students emotional, cognitive, and behavioural outcomes of the SSI work. One construct, concerning the students' motives for learning science, was deleted from this model due to under-sampling of the construct. However, there were indications that a strong desire to earn good grades might have substantial positive impact on outcomes: in fact this single item showed closer association with outcomes than all of the constructs listed in table 1 .

Table 1 Insert below.

By modeling the relationship between the degree of multiethnicity of each school and the average responses at these schools on the questionnaire items, we find differences in some aspects of how the students experienced the SSI work - as well as their attitudes toward, and beliefs about, science and learning science (figure 2). The model describing these differences captured $39 \%$ of the variation in the item responses and explained $85 \%$ of the variation in the

\footnotetext{
${ }^{3}$ A VIP-value higher than 1 means the variable is more important than average, while a VIP below 0.5 indicates that the variable probably is unimportant.
} 
degree of multiethnicity. According to cross-validation, the predictive ability of the twocomponent model was $52 \%$, which is to be considered very high, given the type of data.

Figure 2 Insert here.

A closer analysis of loadings and VIP values, and their confidence intervals for the individual items, reveals that the students in multiethnic schools used internet to a lower extent than students in more monoethnic schools (item 126 in the lower left corner) and more often found the information they encountered too difficult to be useful (item 111 in the upper right corner). Students from multiethnic schools relatively often claim that they believe they learn much from reporting their work to the teacher and their peers $(68,67$ upper right). At the same time they also report, to a higher extent than students from monoethnic schools, that they have not discussed the SSI outside school (126, lower left). They like to work individually (10) and think, to a higher extent than students in monoethnic schools, that they had too much discussion in science class (54). They also found the lack of single correct answers that is inherent in SSI: s frustrating (102) and that [school] science is about learning facts (55). Somewhat surprisingly, at the same time, they thought they generally learn a great deal from discussions during science class (69). Overall, students in multiethnic schools thought, although they did not perceive the SSI-tasks current and related to their everyday lives (128), that school science is about things they want to learn (56) and useful in everyday life (43).

To sum up the quantitative results: the data mainly corroborate earlier research and public debate on differences between mono- and multiethnic classrooms. The results show that students at multiethnic schools have a more authoritative view of knowledge, like to work 
individually to a higher extent, think they have too much discussion in the science classroom, use internet to a lesser extent and do not relate the SSIs to the world outside school or public debate. These aspects can also be described as the core of socio-scientific issues; the idea of using science lessons to develop students' competence in critical thinking, argumentation in groups, information retrieval and to deal with questions that have no right answers. In the following section, we would like to show how these specific aspects were expressed in two different classrooms.

\section{Qualitative study}

In this part we present data from the two schools that were included in the qualitative study. After broad descriptions of the two environments and student groups, we will sum up important themes from the qualitative study from the categories of media use and school culture.

\section{Multiethnic school}

It is the first day of the SSI-project in the multiethnic school. The students, who are aware of that "something" is going to happen, are flocking into the classroom, talking intensely to each other. The teacher, Maria, is standing quietly at the teacher's desk with a smile on her lips. She is waiting until everyone is standing silently at their chairs. -Good morning.

At the whiteboard Maria has written up group divisions, what sources each group should use, and how each group shall present the coming project. The groups are either going to read newspapers or watch television. The presentations are either oral or written.

-Hahaha. You have to write, jeers Ali at another group. 
The students start to discuss the group division and ask what they are going to do. Maria tells them that they are supposed to do their presentations to other students, but to whom is a secret. Maria asks them to note:

- There are some things that are very very important. You are going to make presentations the 26th November. Then she introduces the project with a diary of one day's eating (Field notes, November 14 2008).

Half the students are given a compendium with newspaper articles, carefully chosen by the science teacher and two of her colleagues. The articles are authentic newspaper texts about why Americans get fat, why it is unhealthy to not sleep properly, risks with smoking and additives in food, etc. The other half of the students are shown into either a group room or the computer room to watch films that the teachers had chosen for them. The students are supposed to watch an episode from the TV-show You are what you eat, an informative film about sugar in food and an educative film about training. As well, the whole class is going to watch Supersize me as a special event one afternoon. But before they read the newspapers/watched the TV-shows, the student groups started by doing two mind-maps each, one on the theme 'This is good health' and another on the theme 'This is bad health'. The whole project finished a couple of weeks later with new mind-maps on 'This is good health', since the teachers wanted to know if they had built up their knowledge and changed their opinions.

During the work the teacher, Maria, walks from one group to another, not commenting on their work. To us (the researchers) she was however commenting on the students' behaviour, that most of the time they were where they were supposed to be, doing what they were supposed to do, reading the articles she had handed out to them or watching the television programs. Before the project started Maria had also talked a lot about the importance of working like this, with health issues, since her students often seem to have bad eating and 
sleeping habits - which, according to Maria, influenced their school work. Therefore, the choice of newspaper articles and TV-shows were important and focused on healthy lifestyles, good food and risks with cigarettes in a rather normative way. The students were supposed to get new perspectives on health.

Beside the door in the classroom, someone has hung articles from newspapers. They are all science-related, the black widow spider's establishment amongst Swedish fauna, Nobel prizes, the future research institution ESS and finally an article about insects' space trips. On another wall hangs an illustration with flags from the students' home countries, flowers and black and white hands. Science, mass media and multiethnicity are present in the classroom. One group is supposed to be working with the selected newspaper articles in this room. The group members are sitting with their notebooks open. No one reads the newspaper articles. Fatima has her notebook closed. Laleh starts to write. Viola has her notebook open but doesn't write. The group listens to music on the radio; they don't talk and scarcely write anything. They are mostly sitting staring out through the window (Field notes, November 18, 2008).

On the presentation day, the last day of the project, the 'secret' audience comes to the classroom. It is classmates that have not been involved in the project ('problem students', according to the teacher). The four groups either hand out their written presentation or read from notes in their oral presentation. It is all stories about what they have read or watched, with no interpretations of their own. After that, the project finished with everyone (presenters and audience) in groups making a mind-map each on the theme: This is good health.

\section{Monoethnic school}

During the first lesson at the monoethnic school, the teacher - let us call her Anna - tells the class that they are going to see Morgan Spurlock's documentary film Supersize me. It is a critical film about McDonalds, in which Spurlock himself only ate food from McDonalds for 
one month while at the same time not exercising more than the average American. The film describes how Spurlock's body reacts to the diet and the viewer follows him and his health status during the month. The students watch parts of the film on several occasions. The teacher's thought (not expressed to the students) behind dividing the film into parts was that it was too long to show on one occasion, and that the students were supposed to focus on different body-parts after having seen different passages of the film. She informs the class about the aim of the project: You are going to watch the film and after that look for information on your own. And you should think carefully about one thing: Can you trust McDonalds? (Field notes, November 11, 2008) The students watch the film in silence, except for some comments about Morgan Spurlock's trouble with having sex, about how much soda Americans drink and a lot of sounds showing the student's disgust over a gastric surgery. None of these issues are commented on by the teacher, however.

\begin{abstract}
After the first film segment, the students divided into groups and were told to research information on their own. The students arranged themselves in different places, e.g. in the computer room and in the classroom. Anna, the teacher, walks between the groups answering questions:
\end{abstract}

Lisa: Anna, what are we going to do?

Anna: You are supposed to learn what is good for you to eat, and how your body works. Anna talks for a while about bio-dynamic grown food. When coming to the next group she got the question again and tells them to find out how the liver works.

Anna: If you, for example, eat too much sugar - which parts of your body are involved then? McDonalds has a lot of sugar and salt in their food (Field notes, November 11, 2008).

'I don't know what to do!' is a frequent phrase, and Anna gives them all different answers. But she also acts like a coach, encouraging the students to find information on their own. The 
students' use of media sources is also to a high degree steered by the questions Anna asks the pupils.

The teacher, Anna, joins a group of three boys sitting in front of a computer. Anna asks the group what you need to keep alive. Gabriel answers: nutrients, sugar and protein. What is protein, asks Anna.

After a short while, the group looks at a homepage called "What is protein?" foodinfo.net/se. (Field notes, November 11, 2008)

In other words, the teacher directs the students to work with biological facts. Several times she emphasizes the importance of knowing 'the meatball's route through the body'. She is also trying to lead them into answering these conceptual questions with the help of the internet. Despite this coaching role, the students often seem to be confused over the aim of the task and how they are supposed to use the internet:

Three students sit with a computer each. Julia is using Google and ends up at McDonalds' web page. Gabriel and Sandra are also using McDonalds and Burger Kings websites, looking at pictures of hamburgers and nutrition facts for the products. Gabriel says excitedly:

- Check out the coke. It is quite healthy.

Julia is in despair:

- I don't get this. What are we supposed to do? She repeats this over and over again.

- Where is Anna [the teacher]? We're not getting any help. I am going back to the classroom now (Field notes, 13 Nov, 2008).

On the way back to the classroom Julia talks to Lisa. She repeats her frustration over not understanding what to do and not finding anything relevant on the Internet. Lisa shows her what she has found: a home-page with web-based teaching material, looking very much alike an ordinary text-book. '-Oh, that's really good', says Julia. 
Back in the classroom something happens that is important for the rest of the work. The teacher says: You are going to have a test on December the 4th on the pages 208-222 in the text book. The students make notes immediately in their calendars or in the biology book (Field notes, November 13, 2008). This comment structures the class' further work to a high degree. Now they are going to be tested, just as they are used to. However, they do not seem to be comfortable trying to find out what was important knowledge for themselves. They worry about their grades and about not getting the 'proper' knowledge. At a class meeting, they actually demand that Anna should do as she usually does - lecture them. The biology textbooks also become their primary source for the work. Everyone seems to be satisfied with that solution, and in the beginning of December they have a test on digestion processes which many of the students do well on, according to Anna.

\section{Summary qualitative results}

In both classes we notice that the students are not used to problem-based work and collaboration in autonomous groups. They are uncertain about how to carry out the task and need instructions from the teacher. Despite the fact that the students are used to using the internet, they lack competence in how to retrieve information and critically examine sources. The group's task is usually divided between the group members and they don't use each other as recourses in a collective meaning-making dialogue. In both classes, focus is on reproduction of knowledge/facts, as they use media sources solely as a resource to get facts about health and digestion.

From these observations we can conclude that students in the two classes are in need of another framing concerning their task, if the SSI-characteristics are going to be in focus. The students lack competence in collaborative group. The aims of SSI - such as decision-making, 
ethical reasoning and evidence evaluation - were not apparent to the students. The consequence was that they stuck to the school culture they were used to: namely to reproduce knowledge and consider it as the teacher distributed biological facts through texts (newspapers, TV-shows, internet, school textbooks) and lectures. It is, however, worth noting the differences between the two teachers' ways of organizing the use of media sources. At the multiethnic school, sources are chosen by the teacher and her colleagues. Their criteria were that the texts should be authentic and represent different values. The students were supposed to read them critically, which they didn't. Rather, they used them in the same way as a textbook and tried to learn the content by heart. The students' evaluation of media reporting is on a general level, not connected to the concrete texts and films they are working with. The teacher at the monoethnic school, on the other hand, let the students search for information on their own on the internet - an activity that they obviously had difficulty in doing on their own. This pattern might reflect the teachers' ideas of how a class from a monoethnic, high SES area, or a multiethnic, low SES area, is supposed to be. The idea seems to be that the students in multiethnic classrooms are supposed to have difficulties in looking for information on their own, while the students with Swedish ethnic background, parents with high education and income should be used to researching and scrutinizing information on their own. These observations from the two classrooms are examples of how discourses on how different students are favoured by different work forms are constituted in classroom practices. Other examples of the constituted discourse are e.g. the normative approach in the multiethnic school and the focus on teaching for the test in the monoethnic school. But we will once again emphasize that the aim of this article is to point out the power of discourses rather than intrinsic differences between student groups.

\section{Discussion}


We have noticed clear discursive differences between 'Us' and 'The Other', between monoand multiethnic schools. In a public discourse, it is obvious that there are images of the need to foster children and youngsters with foreign backgrounds (Banks, 2008). According to this discourse they need to be helped to adapt to, for example, Swedish health culture, with proper behavior concerning eating, sleeping, smoking... The Swedish public discourse on schools also emphasizes strict framing in terms of order in multiethnic classrooms in particular, and all classrooms in general. Also, in earlier research (Barton \& Yang 2000; Lee 2003; Parsons, Tran \& Gomillion 2008), images of differences between the different student groups emerge, and we can find these - to some extent - in the results from the questionnaires when the focus is on describing differences between schools with different levels of multiethnicity.

\section{Adaptation to school culture}

On the contrary - in the observation study of the practices in the classroom a different pattern appears. The differences between the classes seem to be smaller with regard to their actions than with regard to statements in the questionnaires. In the observation study it is similarities rather than differences between mono- and multiethnic classrooms that stand out. The quantitative evaluation of the relative influence of different factors on the outcomes of the SSI work supports this observation. This analysis indicates that outcomes, as well as the ways students work with the SSI, are more dependent on the pupils' individual differences in attitudes, epistemological beliefs and self-efficacy than on the degree of multiethnicity of the school. As depicted above, all students are more or less inside the discourse of 'the successful student'. At almost every stage they try to relate to a cultural school code on knowing what is 'proper school knowledge', how to do what the teacher wants them to do, how to get good grades, how to succeed on the test... The students' concepts of how to become a successful student is in line with Broady's (1979) theories on 'hidden curricula'. Rather than being 
active, discussing and using other resources than the textbook or what the teacher has delivered, they sit still and quietly with open textbooks. This is also an obvious result from the quantitative study: the individual goal to succeed in school overshadows all other motivational aspects in education studied in this paper. This applies to the monoethnic as well as the multiethnic classes. The students are well adapted to the school discourse on successful student behavior, but not to a socio-scientific work form. The hopes for making 'science education for all' (Osbourne \& Dillon, 2008, Ratcliffe \& Grace, 2003) are not fulfilled. On the contrary, the work form seems in this case to exclude rather than include students in scientific discourse (c.f. Nyström, 2007, Sadler, 2009).

\section{Teaching a critical literacy}

Noteworthy, however, is that the teachers' role-taking in the classroom corresponds better with the discourse of monoethnic classes as non-authoritarian in their view of knowledge and multiethnic classes as the opposite, than with how their students actually act in the classroom. The teacher at the monoethnic school acted more like a coach, encouraging the students to find information on their own compared with the teacher at the multiethnic school who was busier with character training. Despite information from the researchers on aims and work forms for SSI, the teachers also tended to fall into old habits, e.g. science content is the primary learning goal and their roles were as dispensers of knowledge, delivering facts (Ratcliffe et al 2005) and supervisors. Ekborg et al (forthcoming) are analyzing teachers' views of themselves when working with SSI-tasks. They categorize the teachers as either 'transmitters' or 'guides', based on the teachers' images of themselves. Typical for 'transmitters' is their need to control what the students learn. Characteristic for the 'guides' is their will to start from the student's own questions. From the interviews with the teachers, the 
primary assignment of the science teacher, however, seems to be to teach scientific facts (Ekborg et al, forthcoming).

None of the teachers mention generic skills, as critical thinking, as learning outcomes for the students. These aims are also known by the students. In the monoethnic school they are searching for web pages looking like textbooks, in the multiethnic school the students interpret the normative newspaper articles and TV-shows as 'the truth': what their teachers want them to say and do. In other words, the skills that we (and many before us) pointed out as necessary for a successful work with SSI in the introduction - ability for information retrieval, critical thinking, argumentation and ethical evaluation (see also Ratcliffe \& Grace 2003) - are not on the agenda in the science classroom. This particular kind of framing SSI for tasks is missing, at least as a focused area.

In the questionnaires, the biggest difference between mono- and multiethnic schools was the extent of internet usage. However, the level of internet usage does not inform us about students' information searching strategies or their ability to make use of the information that is found. Indeed, the observations showed that all students - and probably also the teachers (c.f. Jarman \& McClune, 2002, 2009; Elliot, 2006; Halkia \& Mantzouridis, 2005) were illprepared to use any other source than textbooks in science. They had limited skills in information retrieval and critical thinking. Instead, they judged information as reliable if it came from the teacher or seems similar to textbooks - which Lundström (2009) and Lee (2003) also point out in their studies. One implication of the study is therefore that skills such as critical thinking and information retrieval must be focused on in the classroom.

\section{Instrumental and expressive orders}


The picture becomes more complex when Bernstein's (1975) analytical tools are used. According to him, school culture can be distinguished by two orders of activities, which often are in conflict with each other. On the one hand, the school is concerned with the formal learning of facts, skills and understanding - what Bernstein calls the instrumental order. On the other hand, it is concerned with character training including manners and behavior, which constitutes the expressive order. This order is held equally for students and teachers, and tends to bind the school together with collective norms. For the instrumental order, the forms of knowledge, facts, skills and understanding, are often measured and examined and have a direct value for the students' school career. A consequence of this order is that it distinguishes between different groups of students, and has a competing function. Successful students understand the means by which the instrumental and expressive orders are expressed and accept the ends. These students' behavior is committed and they are loyal to the school culture, understand how to deal with school tasks and do them well. They behave in ways accepted by the school in both its instrumental and expressive orders. SSI characteristics such as a cooperative work form, high degree of intellectual autonomy, critical thinking, problem-solving and complex issues without right or wrong answers - might conflict with the school culture manifested by its instrumental and expressive order. Students (and teachers) committed to such school culture are likely to be challenged by the means and ends of SSI, on the one hand by its content and on the other hand by the skills it focuses on. This assumption is supported by the quantitative part of the present study, which indicated that beliefs about learning were at least as influential on perceived learning outcomes and emotional experiences as self-efficacy beliefs and attitudes toward school science (figure and table 1). For example, less positive outcomes from SSI-work were correlated to beliefs that learning science is about remembering facts, rather than participating in knowledge-construction. It was also correlated to the opinion that learning does not benefit from exposing own 
knowledge, in front of the teacher and fellow students. Thus, it seems that students with focus on good grades and an authoritative view on learning and knowledge indeed are disfavored by SSI-tasks. The school discourse on what is the purpose of science learning certainly colors students beliefs and goals (Covington, 2000; Hofer, 2004, 2006). To allow for teaching that provides scope for critical thinking, autonomy and students participating in knowledgeconstruction, not merely as recipients of knowledge, we thus need to be meticulous on what signals regarding the nature knowledge and learning we convey to students through learning objectives, teaching activities or forms of assessment. It is however beyond the scope of this study to discuss how these changes should be brought about.

In our current study, we have observed a tendency for some students - mainly from the multiethnic school - to be involved in the instrumental order at the level of ends, but they cannot fulfill its demands. They accept the learning objectives of SSI, but it is a bit too difficult for them to reach them. They are, however, involved in the expressive order and behave well in class, in line with the school culture, following the teachers' instruction. But they fail to work autonomously in accordance with the SSI idea. The teacher at the multiethnic school is also involved in the expressive order, busy with character training. Her aim is quite normative, for example in changing the students' habits concerning food, drugs and sleep. This should be seen in perspective to the objectives of SSI critical thinking, argumentation and decision making.

We have also noted students, mainly from the monoethnic school, involved in the instrumental order but negative to the expressive order. On the one hand they want to do well and pass the tests with high scores. On the other hand are they eager to criticize work forms that lower their chances of success. This was obvious when some students protested against 
SSI as work form and demanded a return to work forms they were acquainted with. The teacher at the monoethnic school is mainly involved in the instrumental order. Her main aim is to use the task to cover a central part of the science curriculum; the SSI-work was also assessed through an ordinary test on conceptual knowledge, 'the meatball's route through the body'. The teacher at the monoethnic school is concerned about the learning outcome and feeds the students with facts and helps the students to focus on what she thinks is important knowledge and to structure the content. Bernstein (1979) relates means and ends in the orders to class background. The tendencies we observed in our study will be a task for further research. One interesting perspective would be - with help from intersectional theory - to further explore how social class and ethnicity interact both when it comes to discourses on different students' ability to cope with complex issues and concerning students' identity construction in the science classroom.

\section{Discursive collisions}

So, what can we learn from this analysis of how cultural norms and values structure work with socio-scientific issues in mono- and multiethnic schools? On the surface, we can identify needs for structuring SSI-work from the objectives of socio-scientific issues and the aim of developing students' scientific citizenship. On a deeper level, we can understand these problems in terms of what happens when new cultural elements are integrated in a community, when traditional discourses are challenged by new norms. The incorporation of SSI in the science classroom is not done totally painlessly. In our case, we would like to talk about a discursive collision.

One overall aim of SSI is to educate competent citizens and prepare the students for decisionmaking in a complex society (Aikenhead, 2006). The discourse of 'the successful student' 
does not obviously fit in with this aim. The students and the teachers (and of course also ourselves as researchers) seem to be in a conflict zone between school culture and a wish to prepare students for life outside school. We can express it by saying SSI as a work form articulates a collision between different discourses on education; a discourse on differences between students in multiethnic and monoethnic classrooms; a hegemonic school discourse on how to become a successful student; and another on the school's mission to educate active and participating citizens. In the work with the above described SSI-case, it is also possible to identify science discourses, health discourses, body discourses etcetera in the students' and teachers' activities. Schools need to relate to, expose and articulate discursive clashes that emerge when introducing new content and work forms. It is clear that the SSI-work in this case, is helping us to reveal hegemonic discourses in the Swedish school system. Through looking at what is disturbing the order of the school, the prevailing norms become visible and therefore possible to change, to paraphrase Foucault (1967). Fairclough (1995) also write about how what he calls interdiscursivity, meetings (or maybe collisions) between discourses might lead to change in hegemonic discourses. By revealing 'normality' discourses, it will be possible to find new ways of organizing SSI work, where students and teachers are able to deal with the heart of SSI: critical thinking, ethical reasoning, risk analysis and - not least development of scientific citizenship.

\section{Acknowledgements}

The research project SISC is supported by Swedish research council (Grant No 2006-12555). The authors wish to thank Eva Nyström and Margareta Ekborg for valuable feedback.

\section{References}


Aikenhead, G. (2006). Science Education for Everyday Life. New York: Teachers College Press.

Banks, J. (2008). An introduction to multicultural education. Boston: Pearson.

Barton, A.C. \& Yang, K. (2000). The culture of power and science education: Learning from Miguel. Journal of Research in Science Teaching, 35, 379-394.

Bernstein, B. (1975). Class, code and control. London: Taylor and Francis.

Broady, D. (1979). Den dolda läroplanen. (The hidden curricula). Stockholm: Symposion.

Claxton, G. (2008). What's the point of school? Oxford: One word publications.

Clifford, J. \& Marcus, G. (1986). Writing Culture. The Poetics and Politics of Ethnography. Los Angeles: University of California Press.

Covington, M. V. (2000). Goal theory, motivation, and school achievement: an integrative review. Annual Review of Psychology, 51, 171-200.

Cronbach, L.J. (1975) Beyond two disciplines of scientific psychology. American Psychologist, 30, 671-684.

Eagly, A.H. \& Chaiken, S. (1993). The psychology of attitudes. Fort Worth: Harcourt.

Eastment, H.T. \& Krzanowski, W.J. (1982). Cross-validatory choice of the number of components from a principal component analysis, Technometrics 24, 73-77.

Ekborg, M., Ideland, M. \& Malmberg, C. (2009). Science for life - a conceptual framework for construction and analysis of socio-scientific cases. In: NorDiNa 1.

Ekborg, M., Nyström, E. \& Ottander, C. (forthcoming). Teachers and SSI in Sweden. 
Elam, M. \& Bertilsson, M. (2003). Consuming, Engaging and Confronting Science. The Emerging Dimensions of Scientific Citizenship. European Journal of Social Theory, 6, 233-251.

Elliott, P. (2006). Reviewing Newspaper Articles as a Technique for Enhancing the Scientific Literacy of Student-teachers. International Journal of Science Education, 28, $1245-1265$.

Fairclough, N. (1995). Media Discourse. London: Edward Arnold.

Foucault, M. (1967). Madness and Civilization: A History of Insanity in the Age of Reason. London: Tavistock.

Foucault, M. (1981) The order of discourse. In: Young, R (ed): Untying the text. A poststructuralist reader. (pp 52-64). London: Routledge.

Gray, D. S. \& Bryce, T. (2006). Socio-scientific issues in science education: implications for the professional development of teachers. Cambridge Journal of Education, 36, 171-192.

Halkia, K., \& Mantzouridis, D. (2005). Students' views and attitudes towards the communication code used in press articles about science. International Journal of Science Education, 27, 1395-1141.

Hofer, B. K. (2004). Exploring the dimensions of personal epistemology in differing classroom contexts: Student interpretations during the first year of college. Contemporary Educational Psychology, 29, 129-163. 
Hofer, B. K. (2006). Domain specificity of personal epistemology: Resolved questions, persistent issues, new models. International Journal of Educational Research, $45,85-95$.

Ideland, M. (2002). Dagens gennyheter. Hur massmedier berättar om genetik och genteknik. (Gene news of today. How mass media narrate about genetics and gene technology). Lund: Nordic Academic Press. Diss.

Jarman, R. \& McClune, B (2007). Developing scientific literacy: Using news media in the classroom. Maidenhead: Open University Press.

Jarman, R. \& McClune, B. (2002). A survey of the use of newspapers in science instruction by secondary teachers in Northern Ireland. International Journal of Science Education, 24, 997-1020.

Jarman, R., \& McClune, B. (2003). Bringing news reports into the classroom: Citizenship and science education. School Science Review, 84, 121-129.

Lee, O. \& Luykx, A. (2007). Science Education and Student Diversity. I: Abell \& Lederman (eds): Handbook of Research on Science Education (pp 171-197). Mavah NJ: Lawrence Erlbaum.

Lee, O. (2003). Equity for linguistically and culturally diverse students in science education: A research agenda. Teachers college record, 105, 465-489.

Levinson, R., \& Turner, S. (2001). Valuable lessons: Engaging with the social context of science in schools. London: The Wellcome Trust. 
Levinson, R., Koulouris, P. and Turner, S. (2000). Constraints and challenges in teaching about the ethical dilemmas arising from developments in biomedical science. Paper presented at the BERA Conference, Cardiff, 7th September, 2000.

Lorentz, H. (2009). Skolan som mångkulturell arbetsplats. Att tillämpa interkulturell pedagogik. (School as multicultural place of work. How to apply intercultural education). Lund: Studentlitteratur.

Lundström, M. (2009). Vetenskap eller Pseudovetenskap? - En studie om elevers uppfattningar om naturvetenskap, pseudovetenskap och tillförlitlighet.(Science or pseudo-science?) Malmö: Malmö University.

McClune, B. \& Jarman, R (2009). Critical Reading of Science-Based News Reports: Establishing a knowledge, skills and attitudes framework, International Journal of Science Education, 1-26.

Millar, R. \& Osborne, J. E. (Eds.). (1998). Beyond 2000: Science education for the future. London: Kings College London.

Norris, P. \& Phillips, L. M. (2003). How literacy in its fundamental sense is central to scientific literacy. Science Education, 87, 224-240.

Nowotny, H. Scott, P. \& Gibbons, M. (2002). Re-Thinking Science. Knowledge and the Public in an Age of Uncertainty. Cambridge: Polity Press.

Nyström, E. (2007). Talking and taking positions. An encounter between action research and the gendered and racialised discourses of school science. Umeå: Dep. Of Mathematics, Technology and Science Education, Umeå university. Diss.

O’Reilly, K. (2005). Ethnographic methods. New York: Routledge. 
Osborne, J. \& Dillon, J. (2008). Science Education in Europe: Critical reflections. London: Kings College.

Parsons, E. R. C., Tran, L. U., \& Gomillion, C. T. (2008). An investigation of student roles within small, racially mixed science groups: A racial perspective. International Journal of Science Education, 30, 1469-1489.

Parszyk, I-M. (1999). En skola för andra. Minoritetselevers upplevelser av arbets- och livsvillkor i grundskolan. (A school for others. Minority students experiences of work- and life-conditions in compulsory school). HLS Förlag: Stockholm.

Phillips, L. M., \& Norris, S. P. (1999). Interpreting popular reports of science: What happens when the reader's world meets the world on paper? International Journal of Science Education, 21, 317-327.

Ratcliffe, M. \& Grace, M. (2003). Science Education for Citizenship. Maidenhead: Open University Press.

Ratcliffe, M., Bartholomew, H., Hames, V., Hind, A., Leach, J., Millar, R. \& Osborne, J. (2005): Evidence-based practice in science education: the researcher-user interface. Research Papers in Education, No 2, pp 169-186.

Ristilammi, P-M (1994) Rosengård och den svarta poesin. (Rosengård and the black poetry). Stockholm: Symposium.

Roth, W.-M., \& Lee, S. L. (2004). Science education as/for participation in the community. Science Education, 88, 263-291.

Ryan, R. M., \& Deci, E. L. (2000). Intrinsic and Extrinsic Motivations: Classic Definitions and New Directions. Contemporary Educational Psychology, 25, 54-67. 
Sadler, T. (2009). Situated learning in science education: socio-scientific issues as contexts for practice. Studies in Science Education, 45, p 1-42.

Sandström, L. (2004). Rosengård i medieskugga. Om medier som medel och hinder för integration. (Rosengård in media shade. On media as mean and obstacle for integration) Stockholm: Sellin.

Skolverket (2007): PISA 2006 - svenska femtonåringars kunskaper och attityder i ett internationellt perspektiv. (Rapport 254). Stockholm: Skolverket.

Snively, G. \& Corsiglia, J. (2001). Discovering Indigenous Science: Implications for Science Education. Science Education 85, 6-34.

Tytler, R., Osborne, J., Williams, G., Tytler, K., \& Cripps Clarke, J. (2008). A review of the literature concerning supports and barriers to science, technology, engineering and mathematics engagement at primary-secondary transition. Australian Department of Education, Employment and Workplace relations.

Umetrics. (2004). SIMCA-P+ 12. from http://www.umetrics.com/software_simcapplus.asp.

Wigfield, A. \& Eccles, J. S. (2000). Expectancy-Value Theory of achievement motivation. Contemporary Educational Psychology, 25, 68-81.

Willis, P. \& Trondman, M. (2000). Manifesto for Ethnography. Ethnography 2000, 1-5.

Winberg, T. M., \& Lindahl, B. (2008). Science for Life-development of a multi-concept instrument to study the impact of socio-scientific issues on student interest in science. Paper presented at the NFSUN, Nordic Research Symposium on Science Education. 
38 


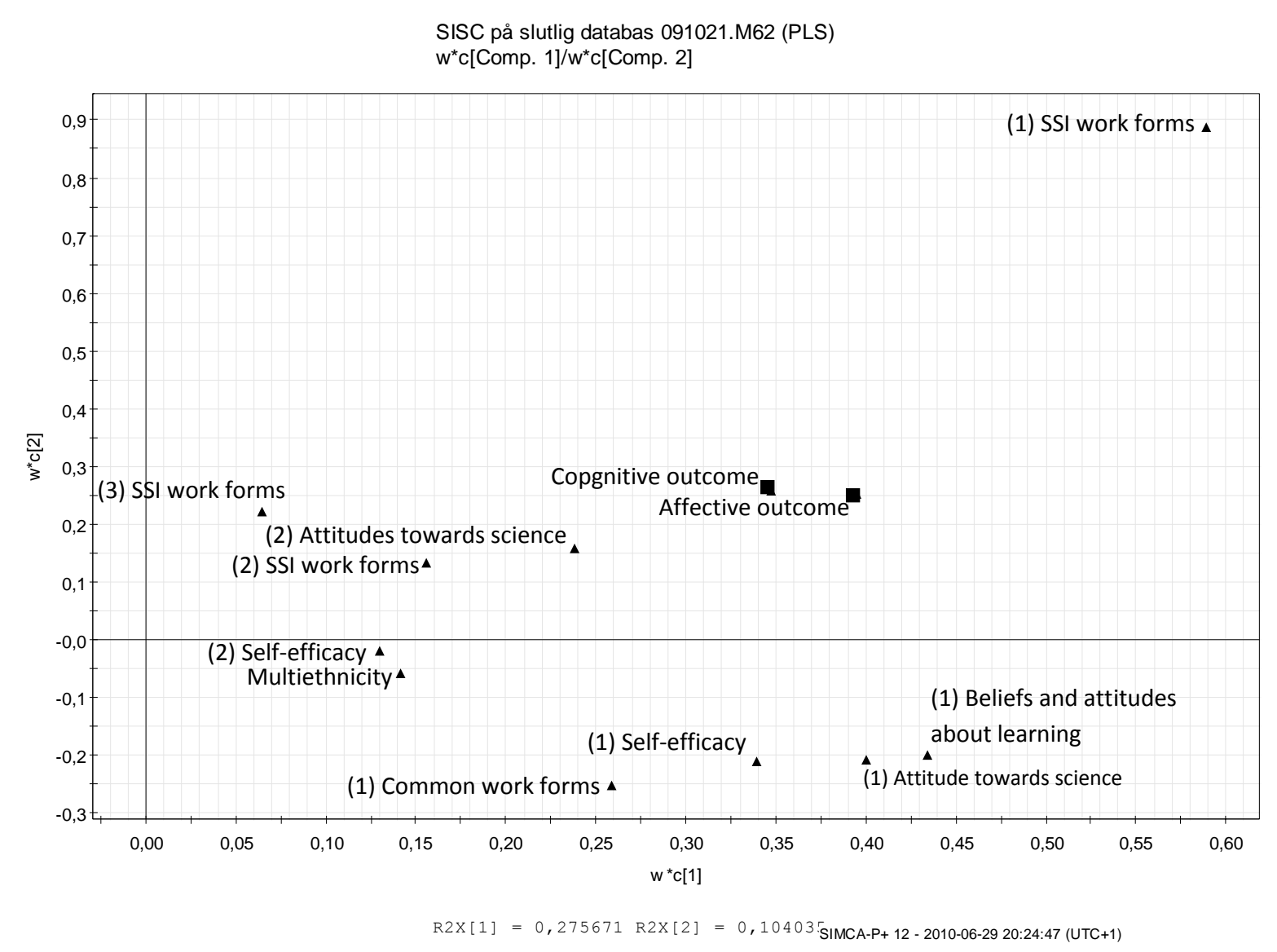


Figure 1. Hierarchical PLS loading plot, illustrating the relationships between the different explanatory constructs (triangles) and the cognitive and affective outcomes (squares). The numbers within brackets that precede the titles of the variables indicate the specific components of the respective base model. For example, the separate base-model of students' attitudes towards science produced two orthogonal components, capturing two different aspects of the attitudes, both included in this PLS analysis as "(1) attitudes toward science" and "(2) attitudes toward science" respectively. 
Figure 2. PLS loading plot showing relationships between the school averages of student responses to the original questionnaire items (triangles) and the degree of multiethnicity (item no 4, filled square). Items located far up to the right or down to the left are the most important for explaining differences in degree of multiethnicity. The distance from the origin of the figure is proportional to the explanatory importance of items. 
Table 1. Results from the hierarchical PLS analysis, showing the relative importance of the listed variables for explaining outcomes of the SSI work, defined as perceived learning, motivated behaviour, and positive affect during SSI work.

\begin{tabular}{lc}
\multicolumn{1}{c}{ Variable } & VIP \\
\cline { 1 - 2 } SSI-work forms, first component & 1,94 \\
Beliefs and attitudes about learning, first component & 1,32 \\
Attitudes, first component & 1,22 \\
Self-efficacy, first component & 1,06 \\
Common work forms & 0,85 \\
Attitudes, second component & 0,70 \\
SSI-work forms, second component & 0,47 \\
Proportion entitled to mother tongue tuition & 0,43 \\
Self-efficacy, second component & 0,38 \\
SSI-work forms, third component & 0,32
\end{tabular}

Differences between students in mono- and multi-ethnic schools ${ }^{1}$ 